\title{
The differential effect of magnesium deficiency on isoenzymes of alkaline phosphatase $(E C$ 3.1.3.1) in rat tissues
}

\author{
BY M. F. NEHLAWI AND F. W. HEATON \\ Department of Biological Sciences, University of Lancaster, Lancaster LAI ${ }_{4} Y Q$
}

(Received I5 November 1978 - Accepted 6 December 1978)

\begin{abstract}
I. Alkaline phosphatase (EC 3. 1.3.1) from many rat tissues was separated into two or three bands by electrophoresis on polyacrylamide gel. Ten of the bands had different electrophoretic mobilities, but some were present in more than one tissue.

2. Bands from the corresponding tissues of magnesium-deficient and control rats were qualitatively similar, but there were quantitative differences in the distribution of enzyme activity between them.

3. $\mathrm{Mg}$ deficiency had differential effects on the absolute activity of individual bands, but two main types of response were observed. There was an increase in the activity of the first bands from liver and kidney, the second band from femur and both bands from spleen, whereas the first band from femur, the first and second bands from intestinal mucosa and the second bands of serum, liver and kidney all decreased in activity during the deficiency.

4. The change in total alkaline phosphatase activity of a tissue during $\mathrm{Mg}$ deficiency depended on the ratio between the enzyme components within it.
\end{abstract}

Magnesium deficiency has been repeatedly found to decrease the serum alkaline phosphatase (EC 3.I.3. I) activity in animals of many species, including cattle, rats and mice (Larvor et al. I964; Heaton, 1965; Hamuro, I971). The enzyme present in serum consists of two (Young, 1967; Langman et al. 1968) or three components (Bussell et al. 1974), and the different isoenzymes are believed to originate from different organs.

Loveless \& Heaton (1976) showed that $\mathrm{Mg}$ deficiency in the rat reduced alkaline phosphatase activity in kidney and bone, as well as in serum, and that the main effect of the deficiency was on the amount of enzyme present rather than on the efficiency of its operation. Inorganic pyrophosphatase (EC 3.6.I.I) usually behaved in the same way as alkaline phosphatase, supporting the concept that the two activities are properties of the same protein molecule (Eaton \& Moss, I967; Fernley \& Walker, I967; Melani \& Farnararo, 1969). Differences were, however, observed in the ratio, alkaline phosphatase:inorganic pyrophosphatase activity between different organs, and in the amount of stimulation produced by exogenous $\mathrm{Mg}$ with the two activities in some tissues, and this caused Loveless \& Heaton (1976) to suggest that isoenzymes of alkaline phosphatase may occur within the same tissue.

Alkaline phosphatase from the small intestine of both rat and mouse has been shown to be heterogeneous (Saini \& Done, 1972; Nayudu \& Hercus, I974; Malik \& Butterworth, 1976) and our preliminary studies indicated that the enzyme extracted from several other organs of normal rats can be separated into two bands by electrophoresis on polyacrylamide gel (Nehlawi \& Heaton, 1978). The present work was therefore undertaken to investigate the effect of $\mathrm{Mg}$ deficiency on the individual components of the enzyme.

\section{EXPERIMENTAL}

\section{Animal management}

Eighteen male Wistar albino rats weighing approximately $100 \mathrm{~g}$ were randomly divided into $\mathrm{Mg}$-deficient and control groups. They were housed three per cage and fed on the appropriate diets for $18 \mathrm{~d}$. All rats received an amount of food equal to that consumed by 
the Mg-deficient animals; this gave an initial intake of $10 \mathrm{~g} / \mathrm{rat}$ per $\mathrm{d}$ reducing to $8 \mathrm{~g} / \mathrm{rat}$ per d. The food was supplied from automatic feeding apparatus (Loveless et al. 1972) to prevent any difference in feeding pattern and distilled water was provided ad lib. The synthetic diets contained $(\mathrm{g} / \mathrm{kg})$ : casein 200 , sucrose 660 , arachis oil 80 , cod-liver oil 20 , salt mixture 40 and purified vitamins, as described previously (Heaton \& Anderson, 1965). They were identical in composition, except for the addition of $\mathrm{MgCl}_{2}$ to the control diet, and the $\mathrm{Mg}$ content determined by analysis was $\mathrm{I} \mathrm{mg} / \mathrm{kg}$ (Mg-deficient) and $780 \mathrm{mg} / \mathrm{kg}$ (control).

Rats were killed by exsanguination from the heart under diethyl ether anaesthesia at the end of the experimental period and perfused through the aorta with $20 \mathrm{ml}$ ice-cold saline ( $9 \mathrm{~g}$ sodium chloride/1). Serum was separated and the liver, small intestine, spleen, both kidneys and both femora were removed as soon as possible. The lumen of the small intestine was flushed with distilled water to remove the contents and the mucosa was separated by cutting the intestine longitudinally, laying flat and scraping with the edge of a microscope slide. All the tissues were stored individually at $-25^{\circ}$ until taken for analysis.

\section{Extraction of enzyme from tissues}

The whole spleen, intestinal mucosa, both kidneys and approximately I g liver were weighed and homogenized separately with $5 \mathrm{ml}$ Io mM-Tris- $\mathrm{HCl}$ buffer, $\mathrm{pH} 7 \cdot 4$, and $3 \mathrm{ml}$ butan-I-ol for $10 \mathrm{~min}$ at $0^{\circ}$ (Morton, 1953), using a top-drive homogenizer (MSE Scientific Instruments, Manor Royal, Crawley, Sussex). After standing at $37^{\circ}$ for $15 \mathrm{~min}$, the homogenate was centrifuged and the lower aqueous layer separated and retained for enzyme assay. Enzyme was extracted from bone by grinding the complete left femur from each rat to a powder and allowing the powder to autolyse in $10 \mathrm{ml}$ distilled water saturated with chloroform for $3 \mathrm{~d}$ at room temperature (Conyers et al. 1967); the clear extract obtained after centrifugation was used for assay.

\section{General analytical methods}

Alkaline phosphatase activity was measured at $\mathrm{pH}$ 10.0 in appropriately diluted serum and tissue extracts by a modification of the $p$-nitrophenyl phosphate hydrolysis method of Bessey et al. (1946). Assays were conducted in medium containing $20 \mathrm{mg}$ exogenous $\mathrm{Mg} / \mathrm{l}$ to provide uniform conditions for activation of the enzyme; the amount of endogenous $\mathrm{Mg}$ from the tissue extracts was negligible at the dilutions used. One unit of enzyme activity is defined as the amount which hydrolysed $1 \mu \mathrm{mol}$ substrate $/ \mathrm{min}$ at $37^{\circ}$ and it is expressed per $\mathrm{ml}$ serum, per $\mathrm{g}$ liver, spleen or kidney, per mg intestinal muscoa nitrogen and per $\mathrm{g}$ dry weight of the contralateral femur.

Protein was determined in homogenates of intestinal mucosa by the method of Lowry et al. (I95I) using bovine serum albumin (Sigma (London) Chemical Co. Ltd, Poole, Dorset) as a standard. The right femur from each rat was dried to constant weight at $105^{\circ}$. $\mathrm{Mg}$ was estimated in serum deproteinized with trichloroacetic acid solution ( $100 \mathrm{~g} / \mathrm{l})$ and in diets that had been dry ashed at $500^{\circ}$ and dissolved in $2 \mathrm{M}$-hydrochloric acid, with an atomic absorption' spectrophotometer (Unicam SP 90). Unknown and standard solutions contained $\mathrm{o} \cdot \mathrm{I} \mathrm{M}-\mathrm{HCl}$ and $2500 \mathrm{mg}$ strontium/l (as strontium chloride) to prevent interference by other constituents of the sample.

The statistical significance of differences was assessed by Student's $t$ test. 


\section{Separation of alkaline phosphatase isoenzymes}

Solutions of serum or tissue extracts containing approximately 0.2 enzyme units $/ \mathrm{ml}$ were mixed with an equal volume of sucrose solution $(0.3 \mathrm{~g} / \mathrm{ml})$ and $50 \mu \mathrm{l}$ of the mixture was placed on top of a gel consisting of a $40 \mathrm{~g}$ acrylamide $/ \mathrm{kg}$ spacer gel $(20 \times 5 \mathrm{~mm})$ followed by

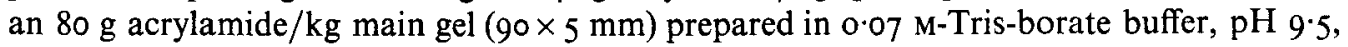
containing $0.25 \mathrm{~mm}$-magnesium chloride. The reservoir buffer was $0.07 \mathrm{M}$-Tris-borate, pH 9.5, containing Io mM-NaCl. Electrophoresis was performed in a cold-room at $4^{\circ}$. Each electrophoretic run contained extracts from tissues of the same rat, and two similar gels were each loaded in the same way with $20 \mu \mathrm{g}$ crystalline bovine haemoglobin (BDH Chemicals Ltd, Poole, Dorset) and included as standards. A current of I mA per tube was applied until the haemoglobin reached the end of the spacer gel, in approximately $10 \mathrm{~min}$, and the current was then raised to $3 \mathrm{~mA}$ per tube and maintained constant for $3 \mathrm{~h}$, by which time the haemoglobin band moved approximately $70 \mathrm{~mm}$ down the main gel. The bands of alkaline phosphatase activity were visualized by incubating the gels with $\alpha$-naphthyl phosphate (100 mg/l; Koch-Light Laboratories Ltd, Colnbrook, Bucks.) and I mM- $\mathrm{MgCl}_{2}$ in $0.05 \mathrm{M}$-borate buffer, $\mathrm{pH} \mathrm{9.7,} \mathrm{for} 30 \mathrm{~min}$ at $37^{\circ}$, washing with distilled water and staining in the dark for $15 \mathrm{~min}$ at $4^{\circ}$ with Fast Blue BB (300 mg/1; Sigma Ltd) and Io $\mathrm{mm}-\mathrm{MgCl}_{2}$ in the same buffer. The gels were washed twice with distilled water and then clarified with four batches of destaining solution containing methanol-acetic acid-glycerol-distilled water (I00:20:6: I00 by vol), the solution being changed every 6-8 h. Gels were kept immersed in distilled water until measured.

The distances moved by the alkaline phosphatase and haemoglobin bands were measured from the junction of the 40 and $80 \mathrm{~g}$ acrylamide $/ \mathrm{kg}$ gels to the centre of each band. The mobility of each enzyme band was expressed relative to that of the haemoglobin standard in the same electrophoretic tank, because this increases the precision of measurement when making comparisons between different electrophoretic runs (Nehlawi \& Heaton, 1978). Intensity of staining was determined by scanning each gel with a Chromoscan recording densitometer (Joyce, Loebl and Co. Ltd, Gateshead) using light of wavelength $550 \mathrm{~nm}$. The area under each peak on the resulting chart was measured with the Chromoscan integrator and related to the total for the whole gel; the enzyme acitivity associated with each band was obtained by applying the ratios for distribution in the gel to the known activity of enzyme that was placed on the gel.

\section{RESULTS}

The mean $( \pm \mathrm{SE}$ ) serum $\mathrm{Mg}$ concentrations of $6.5 \pm 0.2 \mathrm{mg} / \mathrm{l}$ in the $\mathrm{Mg}$-deficient group and $21.9 \pm 0.5 \mathrm{mg} / \mathrm{l}$ in the control group indicated that a severe state of $\mathrm{Mg}$-deficiency was produced, and the final body-weights of the rats in the two groups were $119 \pm 2$ and $139 \pm 2 \mathrm{~g}$ respectively. $\mathrm{Mg}$ deficiency reduced the total alkaline phosphatase activity in serum, kidney and femur (Table I), but the activity in spleen was significantly increased. The weight of the spleen was also greater in $\mathrm{Mg}$-deficient rats $(0.47 \pm 0.02 \mathrm{~g})$ than in controls $(0.32 \pm 0.0 \mathrm{I} \mathrm{g}$; $P<0.0 \mathrm{I})$ despite the smaller body-weight of the $\mathrm{Mg}$-deficient animals.

Electrophoresis on polyacrylamide gel always separated the alkaline phosphatase activity in serum, liver, spleen, kidney and femur into two bands, but the activity in intestinal mucosa separated into three bands (Fig. I). Detailed measurements on the mobility of the individual bands, which are presented in Table 2, showed that the components of the enzyme were qualitatively identical in the corresponding tissues from $\mathrm{Mg}$-deficient and control rats. The mobilities of the two serum components indicated that the first, least mobile, band could correspond to the second band in liver, and second serum band appeared to be similar to the second band in intestinal mucosa. Of the enzyme bands obtained from 
Table I. Alkaline phosphatase activities $\left(\mathrm{EC}_{3}\right.$. I .3.1) (units; $\left.U \dagger\right)$ in tissues from magnesiumdeficient and control rats

(Mean values with their standard errors for nine rats for control group and eight rats for Mg-deficient group)

\begin{tabular}{|c|c|c|c|c|}
\hline \multirow[b]{2}{*}{ Tissue } & \multicolumn{2}{|c|}{ Control } & \multicolumn{2}{|c|}{ Mg-deficient } \\
\hline & Mean & SE & Mean & SE \\
\hline Serum $(\mathrm{U} / \mathrm{ml})$ & 0.384 & 0.025 & $0 \cdot 185$ & $0.01^{* * *}$ \\
\hline Liver $(\mathbf{U} / \mathrm{g})$ & 0.387 & 0.029 & 0.424 & 0.035 \\
\hline Spleen (U/g) & 2.00 & 0.18 & 5.03 & $0.46^{* *}$ \\
\hline Kidney $(\mathrm{U} / \mathrm{g})$ & $24 \cdot 1$ & $\mathrm{I} \cdot 6$ & $18 \cdot 4$ & $0.8^{* *}$ \\
\hline $\begin{array}{l}\text { Intestinal mucosa } \\
\text { (U/mg protein) }\end{array}$ & I $2 \cdot 14$ & $1 \cdot 08$ & 9.54 & 0.96 \\
\hline Femur (U/g dry wt) & $101 \cdot 6$ & $2 \cdot 7$ & $78 \cdot 3$ & $2 \cdot 2 * * *$ \\
\hline
\end{tabular}

Value significantly different from control value: ${ }^{* *} P<0.01,{ }^{* * *} P<0.001$.

$\dagger$ One unit of activity was defined as the amount which hydrolysed I $\mu \mathrm{mol}$ substrate/min at $37^{\circ}$.

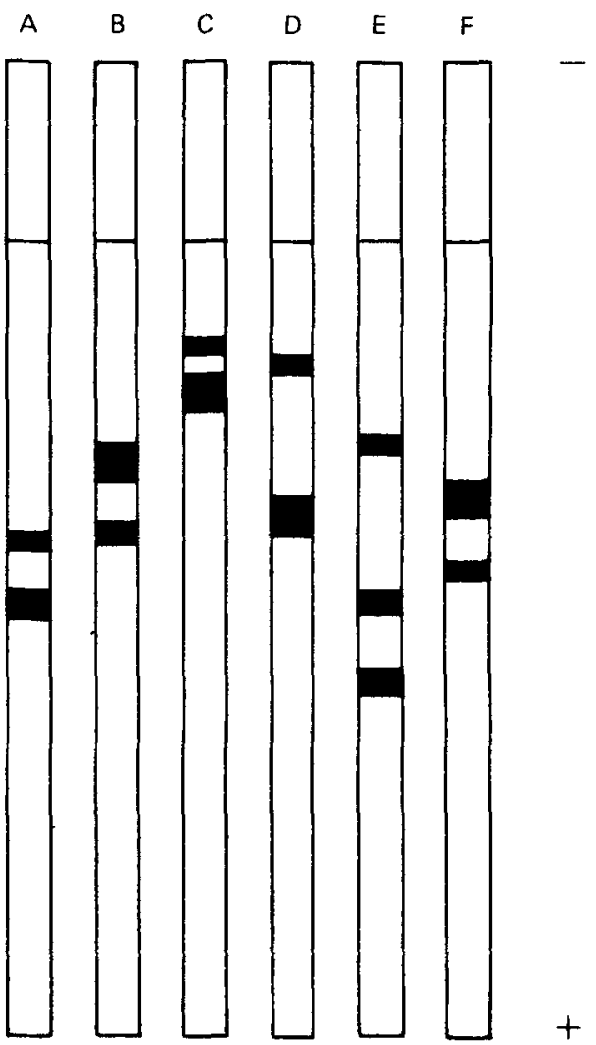

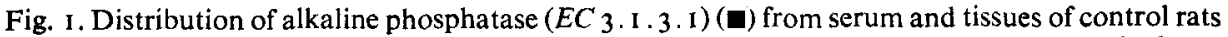
after polyacrylamide gel electrophoresis. A, serum; B, liver; C, spleen; D, kidney; E, intestinal mucosa; $F$, femur.

cellular tissues, femur band I could be similar to kidney band $2(0.3>P>0.2)$, but all the other bands had different mobilities $(P<0.05)$, suggesting the possibility of ten forms of alkaline phosphatase which differ in structure.

Although the enzyme bands were qualitatively similar in the same tissues from both groups of rats, quantitative assessment of the staining intensity on the gels indicated that 
Table 2. Mobilities of serum and tissue alkaline phosphatase (EC 3.1.3.I) isoenzymes from magnesium-deficient and control rats on polyacrylamide gel electrophoresis

(Mean values with their standard errors for nine rats for control group and eight rats for $\mathrm{Mg}$-deficient group; movement from the start of the main gel is given relative to the movement of haemoglobin)

\begin{tabular}{|c|c|c|c|c|c|c|c|}
\hline \multirow[b]{2}{*}{ Tissue } & \multirow[b]{2}{*}{ Group } & \multicolumn{2}{|c|}{ Band I } & \multicolumn{2}{|c|}{ Band 2} & \multicolumn{2}{|c|}{ Band 3} \\
\hline & & Mean & SE & Mean & SE & Mean & $\mathrm{SE}$ \\
\hline Serum & $\begin{array}{l}\text { Control } \\
\text { Mg-deficient }\end{array}$ & $\begin{array}{l}0.343 \\
0.346\end{array}$ & $\begin{array}{l}0.003 \\
0.003\end{array}$ & $\begin{array}{l}0.406 \\
0.409\end{array}$ & $\begin{array}{l}0.004 \\
0.004\end{array}$ & & \\
\hline Liver & $\begin{array}{l}\text { Control } \\
\text { Mg-deficient }\end{array}$ & $\begin{array}{l}0.255 \\
0.256\end{array}$ & $\begin{array}{l}0.006 \\
0.006\end{array}$ & $\begin{array}{l}0.333 \\
0.333\end{array}$ & $\begin{array}{l}0.008 \\
0.007\end{array}$ & & \\
\hline Spleen & $\begin{array}{l}\text { Control } \\
\text { Mg-deficient }\end{array}$ & $\begin{array}{l}0.122 \\
0.124\end{array}$ & $\begin{array}{l}0.006 \\
0.006\end{array}$ & $\begin{array}{l}0.171 \\
0.176\end{array}$ & $\begin{array}{l}0.005 \\
0.004\end{array}$ & & \\
\hline Kidney & $\begin{array}{l}\text { Control } \\
\text { Mg-deficient }\end{array}$ & $\begin{array}{l}0.145 \\
0.145\end{array}$ & $\begin{array}{l}0.004 \\
0.004\end{array}$ & $\begin{array}{l}0.308 \\
0.306\end{array}$ & $\begin{array}{l}0.007 \\
0.007\end{array}$ & & \\
\hline $\begin{array}{l}\text { Intestinal } \\
\text { mucosa }\end{array}$ & $\begin{array}{l}\text { Control } \\
\mathrm{Mg} \text {-deficient }\end{array}$ & $\begin{array}{l}0.234 \\
0.231\end{array}$ & $\begin{array}{l}0.008 \\
0.007\end{array}$ & $\begin{array}{l}0.413 \\
0.412\end{array}$ & $\begin{array}{l}0.013 \\
0.013\end{array}$ & $\begin{array}{l}0.505 \\
0.501\end{array}$ & $\begin{array}{l}0.012 \\
0.011\end{array}$ \\
\hline Femur & $\begin{array}{l}\text { Control } \\
\text { Mg-deficient }\end{array}$ & $\begin{array}{l}0.294 \\
0.289\end{array}$ & $\begin{array}{l}0.009 \\
0.009\end{array}$ & $\begin{array}{l}0.371 \\
0.370\end{array}$ & $\begin{array}{l}0.008 \\
0.007\end{array}$ & & \\
\hline
\end{tabular}

Table 3. Distribution (\% total activity on each gel) of alkaline phosphatase (EC 3. I.3.I) activity among isoenzymes in serum and tissues from magnesium-deficient and control rats

(Mean values with their standard errors for nine rats for control group and eight rats for $\mathrm{Mg}$-deficient group)

\begin{tabular}{|c|c|c|c|c|c|c|c|}
\hline \multirow[b]{2}{*}{ Tissue } & \multirow[b]{2}{*}{ Group } & \multicolumn{2}{|c|}{ Band I } & \multicolumn{2}{|c|}{ Band 2} & \multicolumn{2}{|c|}{ Band 3} \\
\hline & & Mean & SE & Mean & SE & Mean & SE \\
\hline Serum & $\begin{array}{l}\text { Control } \\
\text { Mg-deficient }\end{array}$ & $\begin{array}{l}40 \cdot 0 \\
69 \cdot 2\end{array}$ & $\begin{array}{l}I \cdot 8 \\
I \cdot I * * *\end{array}$ & $\begin{array}{l}60 \cdot 0 \\
30 \cdot 8\end{array}$ & $\begin{array}{l}1 \cdot 8 \\
I \cdot 1 * *\end{array}$ & & \\
\hline Liver & $\begin{array}{l}\text { Control } \\
\text { Mg-deficient }\end{array}$ & $\begin{array}{l}67 \cdot 2 \\
80 \cdot 7\end{array}$ & $\begin{array}{l}2 \cdot 3 \\
3 \cdot 0 * *\end{array}$ & $\begin{array}{l}32 \cdot 8 \\
19 \cdot 3\end{array}$ & $\begin{array}{l}2 \cdot 3 \\
3 \cdot 0^{* *}\end{array}$ & & \\
\hline Spleen & $\begin{array}{l}\text { Control } \\
\text { Mg-deficient }\end{array}$ & $\begin{array}{l}34 \cdot 4 \\
64 \cdot 0\end{array}$ & $\begin{array}{l}I \cdot I \\
0.8 * * *\end{array}$ & $\begin{array}{l}65 \cdot 6 \\
36 \cdot 0\end{array}$ & $\begin{array}{l}I \cdot I \\
0 \cdot 3 * * *\end{array}$ & & \\
\hline Kidney & $\begin{array}{l}\text { Control } \\
\text { Mg-deficient }\end{array}$ & $\begin{array}{l}18 \cdot 7 \\
32.5\end{array}$ & $\begin{array}{l}1 \cdot 0 \\
1 \cdot 0^{* * *}\end{array}$ & $\begin{array}{l}81 \cdot 3 \\
67 \cdot 5\end{array}$ & $\begin{array}{l}I \cdot O \\
I \cdot O * * *\end{array}$ & & \\
\hline $\begin{array}{l}\text { Intestinal } \\
\text { mucosa }\end{array}$ & $\begin{array}{l}\text { Control } \\
\text { Mg-deficient }\end{array}$ & $\begin{array}{r}\text { I I } 0 \\
5 \cdot 3\end{array}$ & $\begin{array}{l}1 \cdot 2 \\
0.5 * *\end{array}$ & $\begin{array}{l}36 \cdot 8 \\
21 \cdot 2\end{array}$ & $\begin{array}{l}2 \cdot I \\
I \cdot I * * *\end{array}$ & $\begin{array}{l}52 \cdot 2 \\
73 \cdot 5\end{array}$ & $\begin{array}{l}2 \cdot 6 \\
{\left[\cdot 4^{* * *}\right.}\end{array}$ \\
\hline Femur & $\begin{array}{l}\text { Control } \\
\text { Mg-deficient }\end{array}$ & $\begin{array}{l}73 \cdot 6 \\
31 \cdot 6\end{array}$ & $\begin{array}{l}0.8 \\
\mathrm{I} \cdot 8^{* * *}\end{array}$ & $\begin{array}{l}26 \cdot 4 \\
68 \cdot 4\end{array}$ & $\begin{array}{l}0.8 \\
I \cdot 8 * * *\end{array}$ & & \\
\hline
\end{tabular}

Value significantly different from control value: ${ }^{* *} P<0.0 \mathrm{I},{ }^{* * *} P<0.00 \mathrm{I}$.

Mg deficiency altered the distribution of activity between the different bands in all tissues (Table 3). In serum, liver, spleen and kidney the proportion of the total activity on each gel associated with band $\mathrm{I}$ increased in $\mathrm{Mg}$ deficiency and the proportion associated with band 2 decreased. The converse applied with femur, and in intestinal mucosa the activity associated with the first two bands decreased and the proportion associated with the third band increased.

The quantitative effect of $\mathrm{Mg}$ deficiency on the activity of each enzyme band is given by the resultant of the changes reported separately in Tables I and 3. The absolute activities of the various bands are given in Table 4 and show that $\mathrm{Mg}$ deficiency had selective effects on individual components of the enzyme. The main effect of the deficiency on serum was to greatly reduce the activity of the second alkaline phosphatase band, but in the other tissues 
Table 4. Activity (units; $U \dagger$ ) of individual alkaline phosphatase (EC 3.I.3.I) isoenzymes in serum and tissues from magnesium-deficient and control rats

(Mean values with their standard errors for nine rats for control group and eight rats for $\mathrm{Mg}$-deficient group)

\begin{tabular}{|c|c|c|c|c|c|c|c|}
\hline \multirow[b]{2}{*}{ Tissue } & \multirow[b]{2}{*}{ Group } & \multicolumn{2}{|c|}{ Band I } & \multicolumn{2}{|c|}{ Band 2} & \multicolumn{2}{|c|}{ Band 3} \\
\hline & & Mean & SE & Mean & SE & Mean & SE \\
\hline Serum $(\mathbf{U} / \mathrm{ml})$ & $\begin{array}{l}\text { Control } \\
\text { Mg-deficient }\end{array}$ & $\begin{array}{l}0.152 \\
0.128\end{array}$ & $\begin{array}{l}0.011 \\
0.010\end{array}$ & $\begin{array}{l}0.232 \\
0.057\end{array}$ & $\begin{array}{l}0.018 \\
0.004^{* * *}\end{array}$ & & \\
\hline Liver $(U / g)$ & $\begin{array}{l}\text { Control } \\
\text { Mg-deficient }\end{array}$ & $\begin{array}{l}0.260 \\
0.342\end{array}$ & $\begin{array}{l}0.004 \\
0.022 * * 1\end{array}$ & $\begin{array}{r}0.127 \\
* 0.082\end{array}$ & $\begin{array}{l}0.012 \\
0.007^{*}\end{array}$ & & \\
\hline Spleen (U/g) & $\begin{array}{l}\text { Control } \\
\text { Mg-deficient }\end{array}$ & $\begin{array}{l}0.69 \\
3.24\end{array}$ & $\begin{array}{l}0.06 \\
0.3 I^{* * *}\end{array}$ & $\begin{array}{l}I \cdot 31 \\
I \cdot 79\end{array}$ & $\begin{array}{l}0.13 \\
0.16^{*}\end{array}$ & & \\
\hline Kidney (U/g) & $\begin{array}{l}\text { Control } \\
\text { Mg-deficient }\end{array}$ & $\begin{array}{l}4 \cdot 60 \\
5 \cdot 95\end{array}$ & $\begin{array}{l}0.37 \\
0.22 * *\end{array}$ & $\begin{array}{l}19.50 \\
12.45\end{array}$ & $\begin{array}{l}\text { I. } 39 \\
0 \cdot 73^{* *}\end{array}$ & & \\
\hline $\begin{array}{l}\text { Intestinal } \\
\text { mucosa (U/mg } \\
\text { protein) }\end{array}$ & $\begin{array}{l}\text { Control } \\
\text { Mg-deficient }\end{array}$ & $\begin{array}{l}I \cdot 32 \\
0.52\end{array}$ & $\begin{array}{l}0.08 \\
0.02^{* *}\end{array}$ & $\begin{array}{l}4 \cdot 5 \mathrm{I} \\
2 \cdot 05\end{array}$ & $\begin{array}{l}0.43 \\
0.12 * * *\end{array}$ & $\begin{array}{l}6 \cdot 31 \\
6 \cdot 97\end{array}$ & $\begin{array}{l}0.34 \\
0.75\end{array}$ \\
\hline $\begin{array}{l}\text { Femur (U/g } \\
\text { dry wt) }\end{array}$ & $\begin{array}{l}\text { Control } \\
\text { Mg-deficient }\end{array}$ & $\begin{array}{l}74 \cdot 8 \\
24 \cdot 7\end{array}$ & $\begin{array}{l}3 \cdot 6 \\
1 \cdot 7^{* * *}\end{array}$ & $\begin{array}{l}26 \cdot 8 \\
53 \cdot 6\end{array}$ & $\begin{array}{l}1 \cdot 0 \\
2 \cdot 7^{* * *}\end{array}$ & & \\
\hline
\end{tabular}

studied it had significant effects on more than one component. In liver, kidney and femur it produced opposite effects on the two components of the enzyme and the change in total activity depended on the relative importance of the two components. The increased total alkaline phosphatase activity found in the spleen during $\mathrm{Mg}$ deficiency was due to enhanced activity by both components of the enzyme.

\section{DISCUSSION}

It is generally accepted that isoenzymes of alkaline phosphatase occur in different mammalian tissues, but our studies show that the enzyme extracted from all the rat tissues examined can be separated into different components by electrophoresis on polyacrylamide gel. These findings are consistent with previous evidence that intestinal alkaline phosphatase is heterogeneous in the rat (Saini \& Done, 1972; Malik \& Butterworth, 1976; Neafsey \& Schwartz, 1977), mouse (Nayudu \& Hercus, 1974) and pig (Colbeau \& Maroux, 1978), and with recent reports that the enzymes from guinea-pig thymus (Fräki et al. 1977) rabbit kidney (Ramadoss et al. 1977) and rat liver (Yokota, I978) can be all separated into two or more components.

The present observations suggest that the rat contains ten different forms of alkaline phosphatase, which are associated in different ways in different tissues (Table 2). This is a surprisingly large number, but all the components were enzymically active and appeared to be distinct by their mobilities on polyacrylamide gel. Nothing is known about the chemical differences between the various bands and it is possible that they may differ in sialic acid content, which has been suggested as an explanation for the differences between alkaline phosphatases from various human tissues (Butterworth \& Moss, I966; Markert \& Whitt, 1968). It seems unlikely that the enzyme would dissociate into subunits under the conditions employed in our work and bands of the same mobility have been obtained consistently during several studies in this laboratory (Nehlawi, 1976).

Whatever the nature of the difference between the various enzyme bands, $\mathrm{Mg}$ deficiency has a marked effect on alkaline phosphatase and the changes in activity of gross tissue 
extracts (Table I) were similar to those reported previously (Loveless \& Heaton, I976). The decreases in total enzyme activity observed in serum, kidney and femur were in each instance due to a major effect of the deficiency on one of the two components in the tissue (Table 4) and the converse effect on spleen was largely due to stimulation of the least-mobile component. The effect of $\mathrm{Mg}$ deficiency on liver, where the increased activity of the first band was almost exactly balanced by the decreased activity of the second band is particularly intriguing.

These findings are difficult to reconcile with the conclusion of Bussell et al. (1974) that $\mathrm{Mg}$ deficiency has a specific effect on the alkaline phosphatase that originates from bone. The more limited studies of these authors were carried out at an earlier stage of depletion and as their serum samples were incubated with neuraminidase ( $E C$ 3.2 I I I8) before electrophoresis, the bands they obtained cannot be validly compared with those in the present work.

Further investigations are needed to define the differences between the various bands having alkaline phosphatase activity, but it is clear that $\mathrm{Mg}$ deficiency has differential effects on individual bands. There do, however, appear to be two distinct types of enzyme component that respond in different ways to the deficiency. The type represented by the first bands of liver and kidney, the second band of femur and both bands of spleen increases in activity during $\mathrm{Mg}$ deficiency, but the type represented by the first band of femur, the first and second bands of intestinal mucosa and the second bands of serum, liver and kidney decreases in activity. The change in total alkaline phosphatase activity observed during $\mathrm{Mg}$ deficiency therefore depends on the ratio between the two types of enzyme component and in most tissues that which undergoes inhibition seems to predominate.

\section{REFERENCES}

Bessey, O. A., Lowry, O. H. \& Brock, M. J. (1946). J. biol. Chem. r64, 32 I.

Bussell, N. E., Vogel, J. J. \& Levy, B. M. (1974). Proc. Soc. exp. Biol. Med. 145, 574.

Butterworth, P. J. \& Moss, D. W. (1966). Nature, Lond. 209, 805.

Colbeau, A. \& Maroux, S. (1978). Biochim. biophys. Acta 51 1, 39

Conyers, B. A. J., Birkett, D. J., Neale, F. C., Posen, S. \& Brudenell-Woods, J. (1967). Biochim. biophys. Acta r39, 363.

Eaton, R. H. \& Moss, D. W. (1967). Biochem. J. 105, 1307.

Fernley, H. N. \& Walker, P. G. (1967). Biochem, J. 104, Ior 1.

Fräki, J., Ruuskanen, O. \& Kouvalainen, K. (1977). Biochim. biophys. Acta 482, 370.

Hamuro, Y. (1971). J. Nutr. ro1, 635.

Heaton, F. W. (1965). Nature, Lond. 207, 1292.

Heaton, F. W. \& Anderson, C. K. (1965). Clin Sci. 28, 99.

Langman, M. J. S., Constantinopoulos, A. \& Bouchier, I. A. D. (1968). Nature, Lond. 217, 863.

Larvor, P., Girard, A., Brochart, M., Parodi, A. \& Sevestre, J. (1964). Annls Biol. anim. Biochim. Biophys. 4, 345.

Loveless, B. W. \& Heaton, F. W. (1976). Br. J. Nutr. 36, 487.

Loveless, B. W., Williams, P. \& Heaton, F. W. (1972). Br. J. Nutr. 28, $26 \mathrm{I}$.

Lowry, O. H., Rosebrough, N. J., Farr, A. L. \& Randall, R. J. (I95I). J. biol. Chem. r93, 265.

Malik, N. \& Butterworth, P. J. (1976). Biochem. Soc. Trans. 4, 646.

Markert, C. L. \& Whitt, G. S. (1968), Experientia 24, 977.

Melani, F. \& Farnararo, M. (1969). Biochim. biophys. Acta r78, 93.

Morton, R. K. (1953). Biochem. J. 55, 786.

Nayudu, P. R. V. \& Hercus, F. B. (1974). Biochem. J. r41, 93.

Neafsey, P. J. \& Schwartz, R. (1977). J. Nutr. 107, 106I.

Nehlawi, M. F. (1976). The effects of magnesium deficiency on isoenzymes of alkaline phosphatase in rat tissues. MSc Thesis, University of Lancaster.

Nehlawi, M. F. \& Heaton, F. W. (1978). Clinica chim. Acta 88, 577.

Ramadoss, C. S., Selvam, R., Shanmugasundaram, K. R. \& Shanmugasundaram, E. R. B. (I977). J. Biochem., Tokyo 8r, I8I3.

Saini, P. K. \& Done, J. (1972). Biochim. biophys. Acta 258, 147.

Yokota, Y. (I978). J. Biochem., Tokyo 83, I 285.

Young, J. M. (I967). J. clin. Path. 20, 647. 